\title{
EL VIENTO AL AMANECER
}

El viento borra las facciones del triste y levanta la falda de los cerros más púdicos.

El viento es poderoso como una serpiente de cristal.

El viento le roba la calma a los místicos

y luego los eleva sobre los edificios y las penas

en un envolvente girar de fenómenos, en un caudaloso y espiralado abrazo de seda y piedra.

El viento se te acerca y te lame las manos mientras recreas en la mente azorada

un cuadro tempestuoso de Turner, una nota sobre huracanes en el Atlántico, el feroz amanecer en las dunas enceguecedoras. 